Western University

Scholarship@Western

Law Publications

Law School

1997

Perceptual Differences in Approaches to Censorship Information Intermediaries and the Implementation of Law

Margaret Ann Wilkinson

Western University, mawilk@uwo.ca

Follow this and additional works at: https://ir.lib.uwo.ca/lawpub

Part of the Law Commons

Citation of this paper:

Wilkinson, Margaret Ann, "Perceptual Differences in Approaches to Censorship Information Intermediaries and the Implementation of Law" (1997). Law Publications. 64.

https://ir.lib.uwo.ca/lawpub/64 


\title{
Perceptual Differences in Approaches to Censorship: Information Intermediaries and the Implementation of Law
}

\author{
MARGARET ANN WILKINSON
}

\author{
Faculty of Law \\ University of Western Ontario \\ London, Ontario, Canada
}

\begin{abstract}
Censorship exists wherever there is preselection of information made available to a particular group of potential users - that is, wherever there is an information intemediary between the information source and the user. Therefore, one cannot ask whether or not there should be censorship. Nor is it realistic to declare that freedom of expression should override censorship. A more useful approach is to ask what checks and balances should be in place to ensure freedom of expression and other basic information rights in the face of the necessity and reality of the information selection pracess. Two forms of legal intervention have been used to create our current regime. This article first examines delegation of the censoring/selecting power to particular intermediaries in the information cycle. Historically, power to select appropriate information for dissemination was delegated to the "censors," and examples of this approach continue in our law in such areas as access and copyright legislation and in unlegislated areas of the law such as confidential information. Second, the paper examines situations where the law regulates the censoring activity itself. In situations such as libel and obscenity, for example, our law preempts the intemediary by dictating the decision itself. The law, however, does not necessarily mirror actual decisions being made by information intenmediaries. Empirical evidence suggests that selection/censorship decisions, which the current law might have been expected to affect, may be being made by other intermediaries and on other criteria than theoretical examination of the law would lead one to expect. These "extralegal" forms of censorship can be very effective, but are we content to leave those decisions without legal control? The article concludes that more strategic empirical analysis of our current legal attempts to create effective checks and balances on the censoring decisions made by intermediaries will assist us in further law reform attempts.
\end{abstract}

Keywords censorship, information policy, intermediaries, law

The role of the censor is probably older than recorded information itself. Certainly the term is derived directly from the Latin. The root Latin verb censere means "to assess, estimate or judge." Of course assessment, estimation, and judgment are central to any process of selectively making available or transmitting information. At the heart of the practices of any information intermediary lie notions of selectively making available to users, from the vast universe of available information, that information that will meet the needs of that information intermediary's client or end user. In performing the function of selectively making information available, the intermediary inevitably deselects some information. That deselected information is then not available in the preselected subset of

Received 15 December 1995; accepted 6 June 1996.

Address correspondence to Margaret Ann Wilkinson. Associate Professor of Law and Library and Information Science, University of Western Ontario, London, Ontario N6A 3K7, Canada. Email: Margaret.Wilkinson@uwoadmin.uwo.ca 
information presented to the end user by the intermediary, from which subset the user then selects the information relevant to his or her needs. The creation by the information intermediary of the deselected subset constitutes censorship because the dissemination of information to that next user in this information chain has been restricted in a way that is beyond that user's control. ${ }^{2}$ Censorship is involved where a restricted dissemination of information occurs; it is not related to the acquisition function.

Preselection before dissemination occurs for many reasons. Users often want to have their information choices restricted through a preselection process. This is the precise function of the reference process in libraries: to deliver a limited amount of information in response to a particular information need. The decision to convey certain information to the user, and not other information, is ideally made on the basis of the information intermediary's professional judgment of the need of the user and the reliability, comprehensiveness, relevance, and accessibility of the information available to meet that need.

In other cases, particular information channels cannot cope with an unlimited volume of information and selection must be made before the channel can be used to further the flow of information. Decisions on what information to collect (and subsequently make available to users) in a certain database or a certain library collection and decisions about what databases to make available require this type of selection (and consequent deselection or censorship).

This discussion thus far has been purely about the role of the information intermediary participating in the information process through the selected dissemination of information. The law only becomes relevant to the question of censorship if we, as a society, believe that there should be control on the social process of censorship. If we are content to leave the selection and consequent censorship of information in the hands of the intermediaries themselves, without social control, then the law has no place in this discussion. It must be recalled, however, in considering this position, that selection and censorship are inevitable given the constraints of users' needs and the available information channels. Therefore, choosing not to legally control censorship would not create complete access for all end users to all information but instead would leave the authority for the selection/censorship decision with the individual intermediary.

One example of such "extralegal" censorship occurred when Lynn Johnston created a story line for her popular comic strip For Better or Worse that involved an identifiably gay character for the first time in mainstream comic history. ${ }^{3}$ This story line defied no legal standard. No legal sanction was sought against the creator. However, very effective censorship power was exercised when a number of the newspapers (the intermediaries) that normally carried the strip suspended publication until that particular story line was concluded. ${ }^{4}$

Another example was the response to the Power Rangers show negotiated between providers of this programming (the intermediaries) and viewers. ${ }^{5}$ In Canada, for example, this negotiation was independent of the legal sanctions of the Canadian Radio and Telecommunications Commission or the Criminal Code. ${ }^{6}$

Another example is the power being exercised by various players acting as intermediaries between the disseminators of information on the networks and the end users in "cyberspace" to block certain types of transmissions."

Assuming, however, for the moment, that we do wish to impose at least some societal controls on the exercise of intermediaries' discretion to select or censor, how can these controls be most effectively and efficiently implemented in law?

One way to begin to answer this question is to examine the current state of the law. In this, we must look at two separate questions. First, where have we attempted, through 
legislation or judicial decisions, to control the selection/censorship decision? Second, how effective has our attempted legal intervention been?

In the space of this article, an exhaustive inventory and evaluation would be impossible. What follows is consideration of selected topics that begin to build a picture of our current situation. In considering the question of the effectiveness of our various legal attempts, it would be useful to be able to call upon relevant empirical research. However, this does not appear to be possible for all areas of the following discussion.

Uniess there is a legal control that dictates otherwise, an information intermediary can take one of two actions regarding the possible further dissemination of any information in his or her possession. Either the intermediary can exercise the power to censor (or obstruct the flow of information to users), that is, to deselect, information. Or the intermediary can choose not to censor a particular work or piece of information-that is, to select it for further dissemination in the channels he or she is controlling. In either case, logically, there are two aspects of the process of selection: the intermediary actor, and the subject matter of the information involved in the decision. The law can intervene to alter the selection decision-making process by affecting either one of these aspects. In any given set of circumstances, either the law can remove the intermediary's decision-making power altogether (and give the decision to select or deselect to another) or the law can dictate what decision, either selection or deselection, the intermediary must make. There are examples of both approaches in our laws.

Since both approaches are possible in law, we may well ask which approach seems to be more effective in the sense of achieving the intended social control. We will return to this theme at the conclusion of our examination of several examples of each approach.

The first group of legal mechanisms discussed is those that have the effect of designating or empowering certain actors in the information process to make the selection decision and therefore prohibiting others from so doing. In situations where this occurs, all others cease to be active intermediaries in the information cycle and become instead simply the facilitators of others' decisions. This legal approach leaves the merits of each individual decision to the actor delegated by society to make the decision. It does not attempt to dictate to the delegate how each decision must be made in particular circumstances. ${ }^{s}$

This is the historical approach to legal control on the selection decision. Indeed, the second dictionary definition of censorship is "the office or power of a censor."

A current example of the legal reallocation of the selection/censorship decision to particular actors is found in Canada in the recent spate of legislation in the area of access to information. Since 1982, nearly every jurisdiction in Canada has moved to stop government from censoring the information which it is prepared to make available to the public. ${ }^{10}$ Access legislation creates the presumption that organizations specifically governed by the legislation cannot, in the absence of a contrary indication in the legislation itself, withhold information from a requester (unless the subject matter is another identifiable individual). In Canadian jurisdictions this removal of the right to censor has been confined to public sector organizations. In creating this legislation through its elected law-making bodies, Canadian society has limited the power to censor heretofore held by certain parties in society, specifically government organizations. This legislation, although available to be used by end users, that is, individual members of the public, is in fact heavily used by the press in Canada, who are themselves information intermediaries." The legislation in this respect, then, has merely shifted the selection/censorship decision from the government, the former intermediaries, into the hands of the private sector press (although they may not be the exclusive channel), the intermediaries who now exercise the selection/censorship power over that information. 
An older, continuing area where law has been used to reallocate the decision power to select or censor is in the area of intellectual property. This area of law began, in the 17th century, to create new rights in the process of information flow. The creation of new rights empowers the new rights holders and in turn gives them some control over the flow of information. An example of this process in intellectual property law can be seen in the area of copyright. ${ }^{12}$ David Vaver catalogues some instances, in various jurisdictions, of the application of copyright law in ways that highlight the censoring capacity of the copyright holders. ${ }^{13}$

The Canadian "fair dealing" exception in copyright is a statutory limitation on the copyright holders' rights to control the dissemination of their works. ${ }^{14}$ In 1988 , Canadian reforms to the copyright statute allowed for the formation of new print copyright owners' collectives, which are now marketing licenses to make certain uses of large collected repertoires. Since 1988, there has been a marked increase in the enforcement of copyright in Canada and an unprecedented round of bargaining with users over rights to use works. These licenses are private contractual arrangements that actually materially affect the information flow process. Are these parties creating more effective channels for use of copyrighted works than exist in the "fair dealing" exemptions in the legislation? It seems important to analyze the actual impact of these relatively new collectives, which have no exact parallel in the American situation, in order to anchor the debate over the fate of the statutory "fair dealing" exception.

Until the "copyright" had been created, there was no ground upon which it was possible to deny anyone the use of an expressed work. ${ }^{15}$ This raises a question in the examination of information flow about whether an expression of a work carries meaning and content beyond the ideas and facts contained in it. This question is important because the legal fiction of the copyright has given the copyright holder control only over expression. That there must be some meaning and content that lies in a work beyond its expression may be inferred, at least to some extent, by the existence of the moral rights in a work separate from the copyrights. The creator's continued control over the moral rights in the work, now clarified and enshrined in the Canadian Copyright Act, ${ }^{16}$ creates another authority, apart from the copyright holder (where the creator no longer holds the entire copyright), entitled to censor or limit the flow of information contained in a work, albeit in certain very limited circumstances. ${ }^{17}$

In discussing copyright, Vaver refers to another area of intellectual property protection as also being an agent of censorship:

The ... myth is that copyright law encourages works to be disseminated. This is largely true if the copyright owner wishes the work to be commercialized or publicized. If he does not, then copyright law with its sidekick, the common law relating to the protection of confidential information, turns into a blunt weapon of censorship. ${ }^{18}$

Our previous examples of legal intervention in the selection/censorship decision in the process of information dissemination (access and copyright law) have been drawn from the legislative or statutory environment. The law governing breach of confidentiality, to which Vaver is drawing our attention, has to date been created exclusively by the judges on a case by case basis. In the commercial context (often referred to as the law of trade secrets), the Supreme Court of Canada, as recently as 1989, has clarified the conditions under which organizations will be entitled to recompense for the unauthorized dissemination of information previously held secret within their own organizational boundaries. ${ }^{19}$ The existence of this right of action for breach of confidentiality effectively 
censors the independent information-disseminating activities of the employees of organizations under certain conditions.

It will be recalled that the second way the law can intervene in the selection/censorship arena is to preempt the decision itself. Such preemption involves society in enshrining the principles which are to guide that decision itself. Such law must per force be involved in the content of the information affected by the decision because the decision to retain or reject information in a particular channel must ultimately refer to a particular content. In theory at least, this approach should ensure consistency in the exercise of the power of selection or censorship throughout society. no matter who exercises it. The problem with enshrining the selecting or censoring decision at this level of authority in our society is that it operates in the first instance in a hortatory or declaratory capacity. ${ }^{20}$ The law does not act in response to particular problems or situations. It leaves the implementation of the decision about further dissemination, which is dictated by the law, to each intermediary who acquires information that is subject to that legislated decision.

Where the law mandates certain selection/censorship actions in respect of information, it could theoretically either impose a positive obligation to make certain information available in the collection or through a particular channel (that is, impose a positive duty to select) or prohibit the dissemination of information, in general or in a particular channel or collection (a duty to censor or deselect).

"Privacy" legislation, which in many provinces of Canada and at the federal level in Canada has accompanied the access legislation discussed earlier, is an area of law that mandates particular decisions about certain information in certain settings. ${ }^{21}$ It is not privacy legislation in the sense of protecting the person from intrusion. ${ }^{22}$ The legislation does not prohibit the collection of information from the individual. Nor does it give the individual complete control over the information once collected. Rather, it requires a public sector organization to make certain selection and censoring decisions in its dissemination activity based on the subject matter of the information. The Canadian province of Quebec has chosen to subject private sector organizations to this regime as well, ${ }^{23}$ The legislation creates a positive duty to disseminate information about an identifiable individual to that individual upon request. The legislation also enshrines a duty not to disseminate information about an identifiable individual to others. The privacy portion of this legislation also has traces of the first type of legal approach, discussed earlier, the creation of a delegated power of decision, in that the identifiable individual does retain some control over the information flow about him- or herself, although that control is not complete. ${ }^{24}$ Whether this legislation is actually changing the behavior of the employees of the affected organizations was the subject of empirical research that I undertook some years ago. I examined a number of organizations subject to the Ontario Freedom of Information and Protection of Privacy Act, $1987 . .^{25} \mathrm{I}$ was disturbed to find that there was not evidence of consistent or widespread change in the information handling practices of employees in these organizations, although ministries had effected greater change than had crown corporations. It appeared that, even where there had been change, information was still flowing in the same directions within and beyond the organizations: All that had changed was the channels (formal and informal) that employees were using. ${ }^{26}$

An example of the development of the common law in the area of preempting the selection or censorship decision is the area of defamation. ${ }^{27}$ There has been some empirical research done in the United States on the advice media lawyers give clients involving defamation issues, which indicates that these lawyers tend to identify a wider ambit of information as information potentially governed by the law in this area than may in fact be the case. Their clients, the information intermediaries, then base their dissemination deci- 
sions on this wider set, therefore censoring dissemination probably more than the law would require. ${ }^{28}$

The final area of law we look at is the classic example of statutory law involved with preempting the selection or censorship decision based upon subject matter: the obscenity prohibitions in criminal law. Specifically we consider the obscenity provisions of the Canadian Criminal Code. ${ }^{29}$ These provisions and the case law that interprets them have been the subject of much learned legal discourse. There has also been considerable social science research activity addressing the various concepts enshrined in the legislation and cases. In this context, however, we are more concerned to discover the actual impact of this area of the law on the information disseminating practices of intermediaries. There does not appear to be direct evidence on this point. On the other hand, there is some empirical work in the context of libraries that can shed some light on the actual selection/ censorship practices of professional information intermediaries in subject areas that are either within or near the subject matter that the obscenity provisions of the law address. Ann Curry finds in her case study:
After detaining copies of American Psycho for two weeks in March 1991, Canada Customs and Excise officials judged that the book was not "obscene" according to the law, and they cleared it for importation from the United States. As far as can be determined, no charges of obscenity have been brought against the book in Canada. However, the influence on librarians of the publicity surrounding possible legal restrictions to freedom of expression cannot be discounted. ${ }^{50}$

She goes on to conclude that:

It appears that when controversy surrounds a new book, many Canadian librarians seek a safe position that does the least harm to any of the tenets of good collection management. The reviews critical of the quality of American Psycho and the reported sex and violence in the book led librarians to de-emphasize the need for anticipating patron demand and prompted them to wait for expressed patron demand, a policy not followed for most books on the best-seller list or featured in the media. ${ }^{31}$

This work indicates that the selection/censorship decision may be driven by a wider perception of the ambit of the law in this area than strict reading of the law would support. A study of the responses of academic libraries in the Canadian Prairie provinces to censorship requests between 1980 and 1985 indicated that in $60 \%$ of cases some kind of deselecting activity resulted. ${ }^{32}$ Moreover, the two principal types of content identified in the challenged material were "(1) material that was sexually explicit or dealt with human reproduction and sexual relations, and (2) material that was alleged to be blasphemous, or that dealt with the occult, or that was otherwise in conflict with the religious affiliation of the parent institution. ${ }^{133}$ In a much larger study of public library responses to censorship requests across Canada, Alvin Schrader again categorized the challenges brought against certain material by subject matter and again the list was far broader than subject matter that could conceivably come within the ambit of the Canadian Criminal Code provisions. ${ }^{34}$ In this study, challenges only resulted in deselecting activity in $28 \%$ of cases. However, Schrader discovered that libraries often reported after-effects of the challenges, tending to lead to further conservatism in selection practices. Moreover, he also indicated that $10 \%$ of the responding libraries, representing almost one-third of the per capita population served by the responding libraries, reported "incidents of collection loss, theft, de- 
facement, alteration, mutilation, or destruction that were suspected by the respondents to have been attempts to prevent or restrict access by others." 35

From this brief review of a number of areas of law that have an impact on the dissemination process, the information policy question that arises is whether the legal mechanisms currently in place are providing effective and appropriate checks and balances to ensure basic freedoms in the face of the selection process. It is apparent that there still remains an important issue of evaluation to be dealt with before we can begin to establish whether the emerging information society requires further or different legal intervention in the censoring activities of actors in the information process. This enquiry must be an empirical one. Who is in a continuing position to make information decisions affecting users further along the path of information flow? How are those decisions being made? Are the legal mechanisms in place actually affecting the intended actors? Are the legal mechanisms in place actually preempting the decision-making process where this is intended, or are the decisions that are actually being made in these areas being made based on criteria other than those imposed by law? Are there other instances of the intermediaries' selection/censorship decision not now governed by law that society now wishes to control?

Returning to a comparison of the two possible avenues of legal intervention in the process, delegation of the decision to specific actors as compared with preemption of the decision by enshrining the criterion for decision making in the law, my preliminary investigations would lead me to advance the tentative hypothesis that although delegating the selecting or censoring decision to the point in the information flow process actually involved in the decision making means that society has less control over the content of that particular decision, it may indeed create a situation where the intervention of society in a particular information cycle can be more effective. Further empirical enquiry could test this hypothesis that laws clearly delegating the decision to disseminate to particular actors are more effective in achieving their stated aims than laws dictating decisions over certain subject matter. Other hypotheses should also be developed and tested empirically. The results, when taken together with such other perspectives as the ethical and international, could indicate a direction for more effective legal intervention. Our efforts should be directed toward developing an appropriate balance between the right of individual intermediaries to control the flow of information through the channels they control and social controls on that flow imposed through law.

Law that ignores the actual process of information flow will be ineffectual in achieving its stated objects. It is in this area of the empirical enquiry into actual information processes that library and information science research, and other branches of empirical enquiry into the information process, have much to contribute to the future development of effective information policy. Information policymakers should examine closely the information intermediaries' perceptions of the dissemination process in order to develop law that effectively implements the desired controls on the inevitable selection/censorship decision process. This can only enhance our societies' abilities to adapt effectively to the rapid changes in information flow currently underway.

\section{Notes}

1. American Heritage Dictionary. (1979).

2. The user can reselect from that information that was made available to him or her if earlier selections are not satisfactory. Therefore, the act of censorship occurs at the level of the intermediary and is not possible at the level of the ultimate end user. 
3. See, for example, London Free Press, 27 March through 3 April 1993, the dates on which the initial story line For Better or For Worse involving the issue of homosexuality appeared.

4. Hugh Mulligan in "Comic History Is Our History" reported in an Associated Press story on 3 August 1993 that more than 50 newspapers had canceled or furloughed the strip. A Canadian Press story released 6 April 1993 reported that while 50 papers temporarily suspended the strip, 19 papers actually canceled the strip. However, it must be recognized that this represents a small percentage of the 1400 papers reported to have previously carried the strip. Those readers of the censoring papers, however, may not have had access to alternative sources, so for them, the censorship would have been complete.

5. Doyle, J. 1994. Why their plug was pulled. Globe and Mail 7 November:A11.

6. Revised Statutes of Canada 1985, c.C-46, as amended.

7. Lewis, P. H. 1994. Censors become a force on cyberspace frontier. New York Tümes 29 June:Alff.

8. However, of course, the characteristics of the intermediary empowered to make the decision may create a bias toward certain selection outcomes. For example, in the past, the Roman Catholic Church acted effectively in western European society to restrict public access to certain literature. The Church continues to select literature for approval but, since the separation of church and state in our governance, its sanction no longer binds western societies, although it may continue to act as an autboritative source of censorship for certain users who accept such authority. See, for example, the following imprint in the New Jerusalem Bible (Garden City, NY: Doubleday, 1985):

Nihil Obstat: John Deehan, M.A., S.T.B., L.S.S. Censor

Imprimatur: $\uparrow$ Cardinal George Basil Hume, O.S.B. Archbishop of Westminster June 18,1985

The Nihil obstat and Imprimatur are a declaration that a book or pamphlet is considered to be free from doctrinal or moral error. It is not implied that those who have granted the Nihil obstat and Imprimatur agree with the contents, opinions or statement expressed.

9. Random House Unabridged Dictionary, 2nd ed. (1993). New York: Random House.

10. See Colin H. H. MeNaim and Christopher D. Woodbury. 1992. Government information: Access and privacy. Toronto: Carswell, with supplements. Access to government information has been legislated in many other jurisdictions, including American jurisdictions, as well.

11. Similar legislation in the United States has been more heavily used by companies for competitive advantage than has been the case in Canada.

12. That control was recently exercised by Canadian composer Murray Schafer, who refused to allow the Toronto Symphony to perform one of his works because, in his view, they are not sufficiently committed to Canadian content. See MacLean's, 1994. 28 November, 107(48):11.

13. An aspect of copyright clearly recognized by David Vaver; see Vaver, D. 1991. Some agnostic observations on intellectual property. Intellectual Property Joumal 6:125-153, esp. 136-139. See also Howell, R, G. 1994. Copyright and obscenity: Should copyright regulate content? Intellectual Property Joumal 8:139-188. Here Howell discusses the possibility of denying copyright protection to certain works on the grounds of illegality as raised in several lower court decisions in Canada. He illustrates that British jurisprudence has denied copyright protection in a wider range of cases. Such denial of copyright protection leaves the creators of those works without the control given other creators, and also denies them the intellectual property in the work with which to trade.

14. This exception roughly corresponds to the American "fair use" exception.

15. See Patterson, L. R. 1968. Copyright in historical perspective. Nashville, TN: Vanderbilt University Press.

16. These same moral rights are not part of the American Copyright Act, but are maybe present through application of otber areas of American law. Commentators differ over whether the United States has yet met its obligations under the Berne Convention to enshrine these rights in law. See further discussion on this point in Wilkinson, M. A. 1996. Anticipating the impact of intellectual property protections. Canadian Joumal of Information and Library Science 21(2), pp. 23-42. 
17. See Wilkinson, M. A., and Kozak, E. 1994. A comparison of U.S. and Canadian copyright law and the effects of NAFTA. In Focus on North American Intellectual Property (Intellectual Property Law Section of the American Bar Association for the 1994 ABA Annual Convention), p. 13. This includes an outline comparison of the American and Canadian positions.

18. Vaver (see note 13), p. 136.

19. LAC Minerals Ltd. v. International Corona Resources Ltd. 1989. 61 Dominion Law Reports (4th) 14 (Supreme Court of Canada).

20. Of course, there are post hoc remedies for not following the dictates of the law in a gived situation.

21. For discussion of this area of law in a comparative context see Flaherty, D. H. 1989. Prolecting privacy in surveillance societies: The Federal Republic of Germany, Sweden, France, Canada and the United States, Chapel Hill: University of North Carolina Press. Also Bennett, C. J. 1992. Regulating privacy: Data protection and public policy in Europe and the United States. Ithaca, NY; Cornell University Press.

22. For a fuller discussion of these points see Wilkinson, M. A. 1992. Impact of the Ontario Freedom of Information and Protection of Privacy Act, 1987 Upon Selected Organizations, pp. 37-42. PhD dissertation, University of Western Ontario.

23. See An Act Respecting the Protection of Personal Information in the Private Sector, Statutes of Quebec 1993, c. 17.

24. That is, the subject individual does retain the right to give consent to dissemination and novel uses.

25. Revised Statutes of Ontario 1990, c.F.31.

26. Wilkinson, M. A. 1993. A study of the effect of controlling the flow of information through imposition of statutes. In Information as a global commodity: Communication, processing and use-Proceedings of the CAIS/ASCI 2Ist Annual Conference, pp. 93-109.

27. There are provincial defamation statutes that have modified some particular aspects of defamation law. See chapter 5.2 of Martin, R., and Adam, G. S. 1994. A sourcebook of Canadian media law, 2nd ed. Ottawa: Carleton University Press. This gives a succinct, recent overview.

28. Susan Shapiro conducted 53 interviews with American media lawyers in 1987. See Shapiro, S. 1989. Libel lawyers as risk counsellors: Pre-publication and pre-broadcast review and the social construction of news, Law and Policy 11:281-308. There does not appear to be similar data for Canada, although Robert Martin argues on the basis of other evidence that there is no "chilling effect" in Canada resulting from our law of defamation. See Martin, R. 1990. Does libel have a "chilling effect" in Canada? Studies in Communications 4:143-163.

29. See particularly the Criminal Code, Revised Statutes of Canada 1985. c.C-46, ss. 163-169. and the leading case of $R$. v, Butler. 1992, 89 Dominion Law Reports (4th) 449 (Supreme Court of Canada).

30. Curry, A. 1994. American Psycho: A collection management survey in Canadian public libraries. Library and Information Science Research 16:201-217, esp. 206.

31. Curry (note 30), p. 215.

32. Schrader, A. M., Herring, M., and de Scossa, C. 1989. The censorship phenomenon in college and research libraries: An investigation of the Canadian Prairie provinces, 1980-1985. College and Research Libraries 50:420-432, esp. 424.

33. Schrader et al. (note 32), p. 423 . It must also be noted that the response rate of $69 \%$ was biased toward smaller institutions.

34. Schrader, A. 1992. A study of the community censorship pressures in Canadian public libraries. Canadian Library Journal 49:29-38, esp. 35.

35. Schrader (note 34), p. 36. 